\title{
Disruptive marketing strategy
}

\author{
G. Tomas M. Hult ${ }^{1}$ (D) - David J. Ketchen $\mathbf{J r}^{2}$
}

Received: 9 May 2017 / Accepted: 21 May 2017 / Published online: 13 June 2017

(C) Academy of Marketing Science 2017

\begin{abstract}
Disruptive marketing strategy is a process by which valuable marketing activities take root initially in applications within a department or function in an organization and then relentlessly move across a company's internal departments/ functions, eventually connecting with external companies to ensure that market-based value creation is delivered to the company's primary stakeholders. Understanding marketbased value creation in the field of marketing has centered, to a large degree, on market orientation studies via field-based, discovery-oriented research. In some ways, market orientation - while viewed as the implementation of the marketing concept - became a disruptive marketing strategy for many organizations. That is, marketing started to permeate all aspects of an organization, and even became a boundary-spanning phenomenon connecting multiple companies. The activities in marketing moved beyond their traditional home department and the marketing function became cross-departmental and even, in some cases, cross-company focused. Where do we go next? Disruptive marketing strategy will help the field and practice of marketing evolve.
\end{abstract}

Keywords Disruptive marketing strategy $\cdot$ Market orientation $\cdot$ Marketing organization $\cdot$ Sustainability

G. Tomas M. Hult

hult@msu.edu

1 Broad College of Business, Michigan State University, East Lansing, MI 48824-1121, USA

2 Harbert College of Business, Auburn University, Auburn, AL 36849-5241, USA

\section{Introduction}

As a theoretical backbone to market orientation, the marketing concept has been an important foundation of the boundaryspanning role of marketing for more than half a century (Lafferty and Hult 2001). Keith (1960, pp. 36-38) introduced this boundary-spanning evolution of marketing in 1960 by focusing on the "marketing company ... [where] marketing permeates the entire organization ... [and] we are moving from a company which has the marketing concept to a marketing company." Hult (2011a, p. 509) capitalized on this evolution by delineating the ideas for a "theory of the boundary-spanning marketing organization" that placed emphasis on boundaryspanning not just across functions or departments within an organization but also between companies.

Consequently, a focus on the idea of a marketing company allows for the unique positioning of marketing within an organization to not be attached to a department or function (Walker and Ruekert 1987), although it could be, but instead be based on a set of cross-functional/departmental activities (Vorhies and Morgan 2005). Additionally, the classical "theory of the firm" perspective (e.g., Coase 1937) has become just one of several architectural structure options for companies, with the advent of open source activities, cloud-based undertakings, and eCommerce exchanges, to name a few disruptive innovations in the spirit of Christensen's (2013) tone setting work.

Christensen emphasizes that his disruptive innovation perspective "describes a process by which a product or service takes root initially in simple applications at the bottom of a market and then relentlessly moves up market, eventually displacing established competitors" (claytonchristensen.com). In a similar way, as it relates to market orientation and marketing organizations, disruptive marketing strategy is a process by which valuable marketing activities take root initially in applications within a department or function in an organization 
and then relentlessly move across a company's internal departments/functions, eventually connecting with external companies to ensure that market-based value creation is delivered to the company's primary stakeholders. These disruptive marketing activities can center on administrative, process, and/ or product/service innovations (Hurley and Hult 1998; Ozkaya et al. 2015).

\section{Boundary-spanning marketing organization}

Much of the need for a continuous disruptive marketing lens can be explained by the need for a contemporary fit among business strategy, marketing organization structure, and strategic behavior (Olson et al. 2005); marketing-driven supply chain operations (Kozlenkova et al. 2015); and companies' constant striving for superior marketing performance (Katsikeas et al. 2016). Layered together, a focus on internal and external marketing activities (Day 1994) within the structure of the core customer value-creating processes of product development management, customer relationship management, and supply chain management (e.g., Lehmann and Jocz 1997; Srivastava et al. 1999) at the level of complexity inherent in an organization's network arrangements (Achrol and Kotler 1999) make up the pillars of the theory of the boundary-spanning marketing organization (Hult 2011a). As shown in Fig. 1, this theory builds on the synergy that exists and should be drawn out between marketing and organization theory (Ketchen and Hult 2011).

Emphasizing activities instead of the marketing function or department also allows marketing to infiltrate the whole organization (Homburg and Pflesser 2000), or at least large parts of it, and serves to fuse together the "network of specialized organizations [that have become] the organizations of the future" (Achrol 1991, p. 78). This "activities focus" can be said to have been the motivation for the marketing field's exponential increase in attention to market orientation that started in full effect about three decades after Keith's (1960) "marketing company" research. Basically, the implementation of the marketing concept - which we have come to call "market orien- tation" - became in vogue in the late 1980s (e.g., Shapiro 1988). Due to the fundamental importance attributed to the marketing concept initially and market orientation later on, numerous research projects have defined the constructs related to the phenomenon and explored their application and implementation in business (with more than 1000 articles published on market orientation since 1990, as pointed out by Jaworski and Kohli 2017).

\section{Five perspectives on market orientation}

Around the late 1980s and early 1990s, the marketing literature assumed that the "marketing concept" was present, important, and viable as a strategic positioning for companies (Lafferty and Hult 2001). As a result, the field largely moved on to market orientation as a way to focus on the implementation of the marketing concept. At the early stage of the study of market orientation, five perspectives on market orientation were advanced in the literature, as shown in Fig. 2, with each taking a different approach to the definitional boundaries and conceptualization of the phenomenon (see Lafferty and Hult 2001 for an integrative summary of each perspective):

1. Decision-making perspective (Shapiro 1988)

2. Market intelligence perspective (Kohli and Jaworski 1990)

3. Culturally based behavioral perspective (Narver and Slater 1990)

4. Strategic perspective (Ruekert 1992)

5. Customer orientation perspective (Deshpande et al. 1993)

Shapiro (1988) led the charge of the "decision-making perspective" of market orientation. His view was that "it's far more than the cliché getting close to the customer ... the term market oriented represents a set of processes touching all aspects of the company" (p. 120). Shapiro (1988) specified three characteristics that make a company market oriented: (1) Information on all important buying influences permeates
Fig. 1 Toward a theory of the boundary-spanning marketing organization

\section{Toward a Theory of the Boundary-Spanning Marketing Organization}

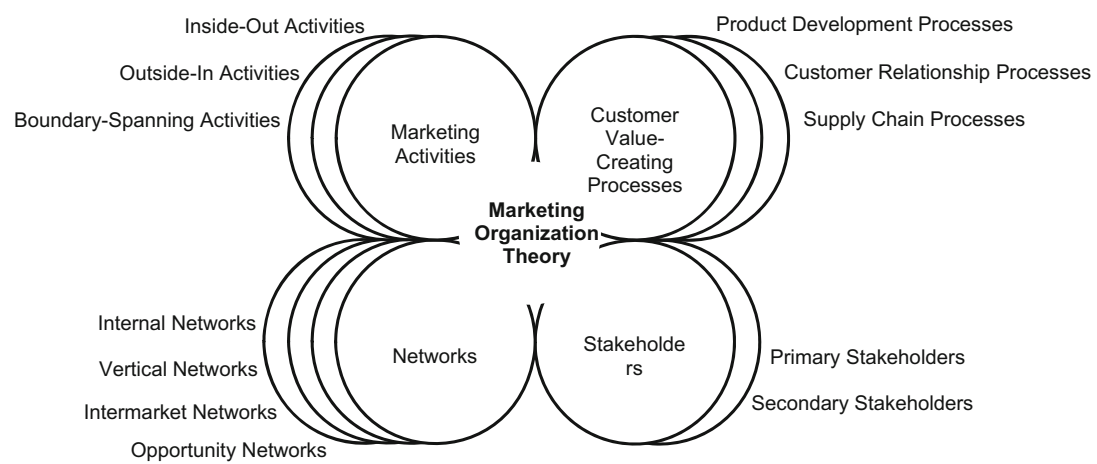




\section{Synthesizing Market Orientation}

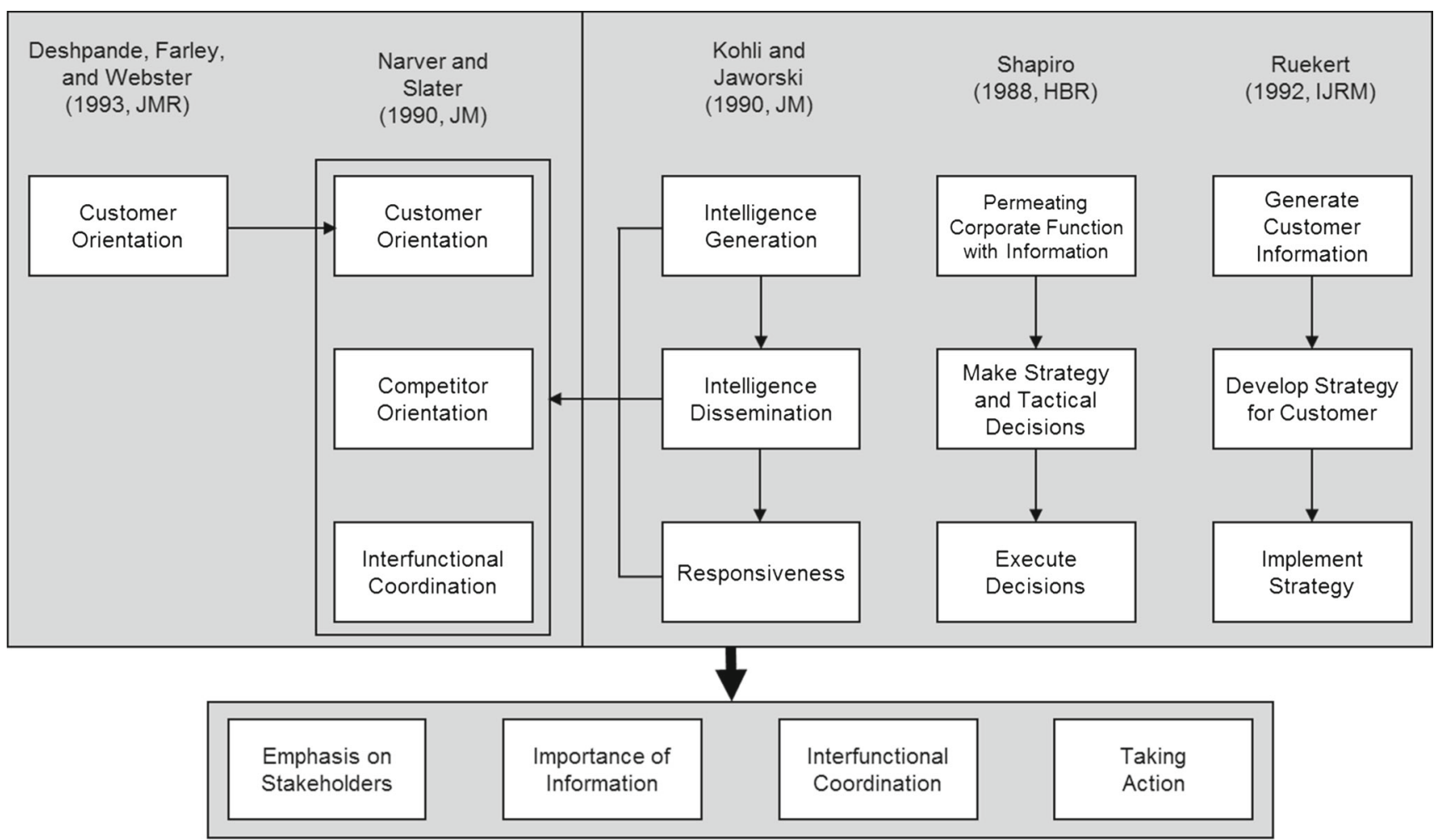

Synthesis Dimensions of Market Orientation

Fig. 2 Synthesizing market orientation

every corporate function (p. 120); (2) Strategic and tactical decisions are made interfunctionally and interdivisionally (p.121); and (3) Divisions and functions make well-coordinated decisions and execute them with a sense of commitment (p. 122).

Next came the "market intelligence perspective" of market orientation - as exemplified by Kohli and Jaworski (1990, p. 6): "Market orientation is the organization-wide generation of market intelligence pertaining to current and future customer needs, dissemination of the intelligence across departments, and organization-wide responsiveness to it." In that same time period, Narver and Slater (1990, p. 21) emphasized the "culturally based behavioral perspective" of market orientation. From their perspective, "market orientation is the organizational culture that most effectively and efficiently creates the necessary behaviors for the creation of superior value for buyers and, thus, continues superior performance for the business".

Ruekert (1992, p. 228) added on the "strategic focus perspective" of market orientation which suggested that "the level of market orientation in a business unit is the degree to which the business unit obtains and uses information from customers, develops a strategy which will meet customer needs, and implements that strategy by being responsive to customer needs and wants." And, finally, just five years after Shapiro's work was published, Deshpande et al. (1993), p. 27) focused more narrowly on the "customer orientation perspective" of market orientation. In their view, "customer orientation is the set of beliefs that puts the customer's interest first, while not excluding those of all other stakeholders such as owners, managers, and employees, in order to develop a long-term profitable enterprise".

In some ways, Deshpande et al. (1993) customer orientation research led many in marketing strategy's neighboring field - strategic management - to assume that market orientation was synonymous with customer orientation (e.g., Connor 1999). As a consequence, in a series of Strategic Management Journal articles spanning 1996 to 2007, the phenomenon of market orientation was discussed and debated (Christensen and Bower 1996; Connor 1999, 2007; Hult and Ketchen 2001; Ketchen et al. 2007; Slater and Narver 1998, 1999). At one point, Slater and Narver $(1998,1999)$ "took on" the strategic management viewpoint (Christensen and Bower 1996; Connor 1999), and then Slater joined forces with Hult et al. (2005) as a "united" marketing strategy perspective, followed by misunderstandings (Connor 2007) and clarifications (Ketchen et al. 2007). Ultimately, the conclusion was of course that customer orientation is not synonymous with market orientation, which is a broader phenomenon stemming from the marketing concept platform. 


\section{Levels and changes in market orientation}

Today, it is a rarity to see scholars concentrating on the marketing concept, per se, and research on market orientation has also evolved a lot since those early days in the late 1980 s. Current research assumes that marketing in general includes vital business activities (e.g., Feng et al. 2015) and that there is a strategic "concept" of marketing embedded in most, if not all, viable revenue-generating organizations (Varadarajan $2010,2015)$ that can be capitalized on by being market oriented (cf. Kumar et al. 2011). Hult and Ketchen (2001, p. 899) tested the idea of capitalizing on market orientation by empirically addressing a simple question: Does market orientation matter? Their testing ultimately said "yes," of course, but the capitalization on market orientation was dependent on the positional advantage (Day and Wensley (1988) of market orientation vis-à-vis its relationship with a company's performance (see, for example, the marketing-performance outcome chain in Fig. 1 in Katsikeas et al. 2016).

At this stage of theoretical, conceptual, and empirical development of market orientation, the presence, or achieved level, of market orientation is still an important aspect of market orientation research. However, more importantly, the need for change and the changes in market orientation appear to be more logical and vital focus areas for research (cf. Kumar et al. 2011). In fact, studying levels of market orientation without also considering the changes in those levels of market orientation between time periods likely skews findings and distorts implications which in turn twists our understanding of the value of market orientation to the field of marketing and to companies (cf. Fornell et al. 2016a, 2016b).

\section{Market orientation plus!}

Additionally, as suggested in Hult (2011b, p. 1) and shown in Fig. 3, "the concept of sustainability is increasingly being addressed theoretically by scholars and practically by managers and policymakers as it relates to being market oriented. With a growing focus on sustainability efforts, marketing is in a unique position to elevate its focus from managing relationships with customers to strategically managing a broader set of marketplace issues." Related to market orientation, "an organization achieves marketbased sustainability to the extent that it strategically aligns itself with the market-oriented product needs and wants of customers and the interests of multiple stakeholders concerned about social responsibility issues involving economic, environmental, and social dimensions." Hult (2011b) called this "market orientation plus!"

Finally, while there is convenient overlap and oftentimes synergy that exist between marketing - and market orientation in particular - and organization theory

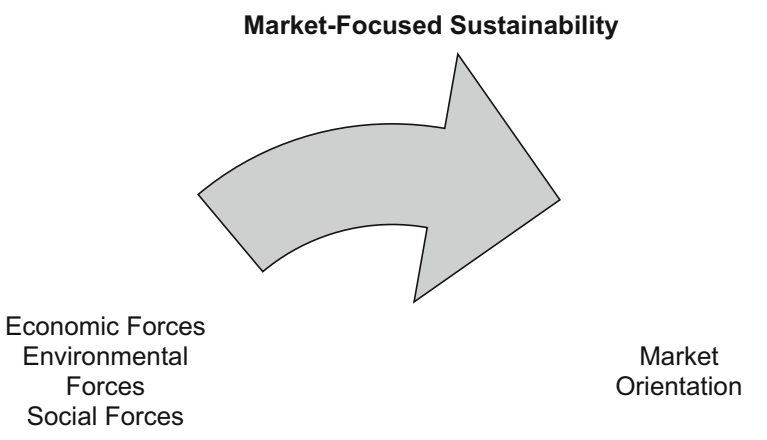

CUSTOMERS

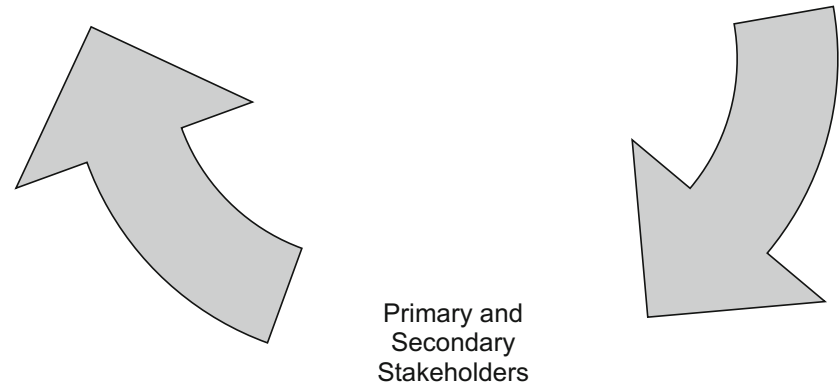

Fig. 3 Market-focused sustainability

(Ketchen and Hult 2011), various theoretical lenses clearly have opportunities to provide different descriptions, predictions, and explanations of the performance effects of market orientation in diverse organizations and diverse contexts. The 31 organization theories reviewed in Hult (2011a) can be a starting point for a deeper treatment of the antecedents and consequences of market orientation, as market orientation evolves into a more complex boundaryspanning phenomenon centered on stakeholder value creation and delivery in contemporary market settings.

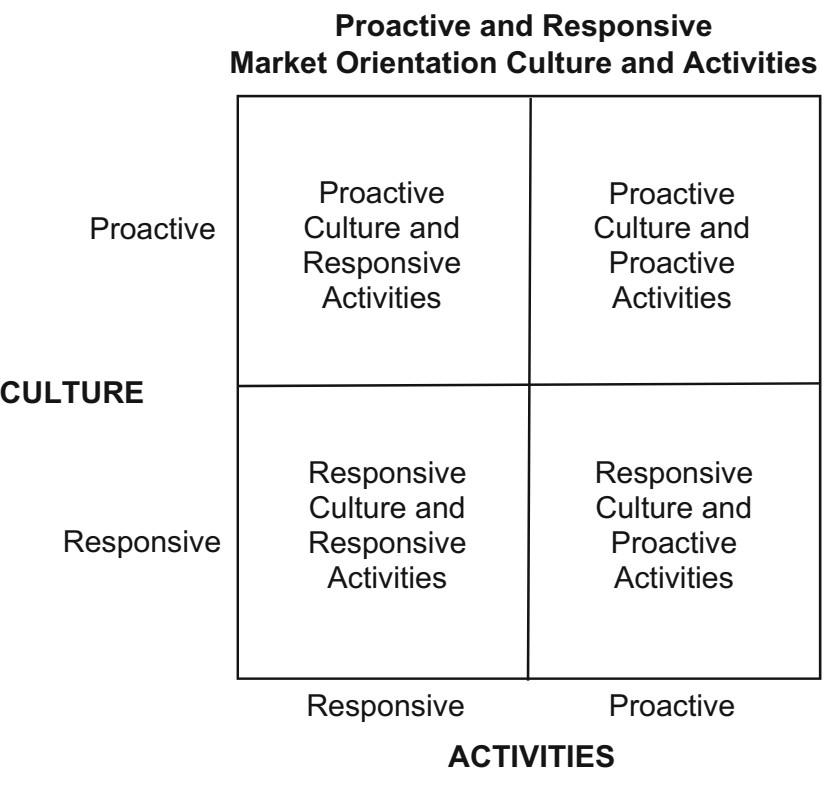

Fig. 4 Proactive and responsive market orientation culture and activities 


\section{Conclusion}

The last of the five perspectives on market orientation - introduced by Deshpande et al. (1993) as the "customer orientation perspective" - may have created more confusion about what market orientation really is than helped the ongoing delineation and use of market orientation. In fact, Deshpande and Farley (1998a, b) even changed their own view about this orientation being culturally versus behaviorally based, which did not help the argument (Narver and Slater 1998a, 1998b). But, the questions remain interesting: (1) Can market orientation be inherent in an organization's culture in addition to its activities?; Can market orientation be inherent in crosscompany ventures independent of its ties to the parent organization?; and Can market orientation be proactive and/or responsive in both an organization's culture and its activities? If yes is the answer to the latter, we wonder what outcomes can we expect to see when the culture is proactive but the activities are responsive/reactive (Narver et al. 2004), if that is even possible. Plus, by extension what might be the expected operational and performance outcomes of the four cells in Fig. 4, and which cell is most likely to find companies that create disruptive marketing strategies? The easy answer may be the "Proactive Culture and Proactive Activities" cell in the twoby-two matrix but that likely simplifies the answer too much!

\section{References}

Achrol, R. S. (1991). Evolution of the marketing organization: New forms for dynamic environments. Journal of Marketing, 55(October), 77-93.

Achrol, R. S., \& Kotler, P. (1999). Marketing in the Network Economy. Journal of Marketing, 63(Special Issue), 146-163.

Christensen, C. M. (2013). The innovators dilemma: When new technologies cause great firms to fail. Boston: Harvard Business Review Press.

Christensen, C. M., \& Bower, J. L. (1996). Customer power, strategic investment, and the failure of leading firms. Strategic Management Journal, 17(3), 197-218.

Coase, R. H. (1937). The nature of the firm. Economica, 4(16), 386-405.

Connor, T. (1999). Customer-led and market-oriented: A matter of balance. Strategic Management Journal, 20(12), 1157-1163.

Connor, T. (2007). Market orientation and performance. Strategic Management Journal, 28(9), 957-959.

Day, G. S. (1994). The capabilities of market-driven organizations. Journal of Marketing, 58(October), 37-52.

Day, G. S., \& Wensley, R. (1988). Assessing Advantage: A Framework for Diagnosing Competitive Superiority. Journal of Marketing, 52(April), 1-20.

Deshpande, R., \& Farley, J. U. (1998a). The market orientation construct: Correlations, culture, and comprehensiveness. Journal of MarketFocused Management, 2(3), 237-239.

Deshpande, R., \& Farley, J. U. (1998b). Measuring market orientation: Generalization and synthesis. Journal of Market-Focused Management, 2(3), 213-232.
Deshpande, R., Farley, J. U., \& Webster, F. (1993). Corporate culture, customer orientation, and innovativeness in Japanese firms: A Quadrad analysis. Journal of Marketing, 57(January), 23-37.

Feng, H., Morgan, N. A., \& Rego, L. L. (2015). Marketing department power and firm performance. Journal of Marketing, 79(September), $1-20$.

Fornell, C., Morgeson III, F. V., \& Hult, G. T. M. (2016a). Stock returns on customer satisfaction do beat the market: Gauging the effect of a marketing intangible. Journal of Marketing, 80(5), 92-107.

Fornell, Claes, Forrest V. Morgeson III, and G. Tomas M. Hult (2016b), "An abnormally abnormal intangible: Stock returns on customer satisfaction." Journal of Marketing, 80 (5), 122-125.

Homburg, C., \& Pflesser, C. (2000). A Multiple-Layer Model of MarketOriented Organizational Culture: Measurement Issues and Performance Outcomes. Journal of Marketing Research, 37(November), 449-462.

Hult, G. T. M. (2011a). Toward a theory of the boundary-spanning marketing organization and insights from 31 organization theories. Journal of the Academy of Marketing Science, 39(4), 509-536.

Hult, G. T. M. (2011b). Market-focused sustainability: Market orientation plus! Journal of the Academy of Marketing Science, 39(1), 1-6.

Hult, G. T. M., \& Ketchen Jr., D. J. (2001). Does market orientation matter?: A test of the relationship between positional advantage and performance. Strategic Management Journal, 22(9), 899-906.

Hult, G. T. M., Ketchen Jr., D. J., \& Slater, S. F. (2005). Market orientation and performance: An integration of disparate approaches. Strategic Management Journal, 26(12), 1173-1181.

Hurley, R. F., \& Hult, G. T. M. (1998). Innovation, market orientation, and organizational learning: An integration and empirical examination. Journal of Marketing, 62(July), 42-54.

Jaworski, B. J. \& Kohli, A. K. (2017). Conducting field-based, discoveryoriented research: Lessons from our market orientation research experience. AMS Review, 7 (1/2), In Press.

Katsikeas, C. S., Morgan, N. A., Leonidou, L. C., \& Hult, G. T. M. (2016). Assessing performance outcomes in marketing. Journal of Marketing, 80(2), 1-20.

Keith, R. J. (1960). The marketing revolution. Journal of Marketing, 24(3), 35-38.

Ketchen, D. J., \& Hult, G. T. M. (2011). Marketing and organization theory: Opportunities for synergy. Journal of the Academy of Marketing Science, 39(4), 481-483.

Ketchen Jr., D. J., Hult, G. T. M., \& Slater, S. F. (2007). Toward greater understanding of market orientation and the resource-based view. Strategic Management Journal, 28(9), 961-964.

Kohli, A. K., \& Jaworski, B. J. (1990). Market orientation: The construct, research propositions, and managerial implications. Journal of Marketing, 54(April), 1-18.

Kozlenkova, I., Hult, G. T. M., Lund, D., Mena, J. A., \& Kekec, P. (2015). The role of marketing channels in supply chain management: A Review of the literature and takeaways for future research. Journal of Retailing, 91(4), 586-609.

Kumar, V., Jones, E., Venkatesan, R., \& Leone, R. P. (2011). Is market orientation a source of sustainable Competitive advantage or simply the cost of competing? Journal of Marketing, 75(January), 16-30.

Lafferty, B. A., \& Hult, G. T. M. (2001). A synthesis of contemporary market orientation perspectives. European Journal of Marketing, 35(1), 92-109.

Lehmann, D. R., \& Jocz, K. E. (1997). Reflections on the futures of marketing. Cambridge: Marketing Science Institute.

Narver, J. C., \& Slater, S. F. (1990). The effect of a market orientation on business profitability. Journal of Marketing, 54(4), 20-35.

Narver, J. C., \& Slater, S. F. (1998a). Creating a market orientation. Journal of Market-Focused Management, 2(3), 241-255.

Narver, J. C., \& Slater, S. F. (1998b). Additional thoughts on the measurement of market orientation: A comment on Deshpande and Farley. Journal of Market-Focused Management, 2(3), 233-236. 
Narver, J. C., Slater, S. F., \& MacLachlan, D. L. (2004). Responsive and proactive market orientation and new-product success. Journal of Product Innovation Management, 21(5), 334-347.

Olson, E. M., Slater, S. F., \& Hult, G. T. M. (2005). The performance implications of fit among business strategy, marketing organization structure, and strategic behavior. Journal of Marketing, 69(July), 49-65.

Ozkaya, E., Cornelia, D., Hult, G. T. M., Calantone, R., \& Ozkaya, E. (2015). Market orientation, knowledge competence, and innovation. International Journal of Research in Marketing, 32(3), 309-318.

Ruekert, R. W. (1992). Developing a market orientation: An organizational strategy perspective. International Journal of Research in Marketing, 9(3), 225-245.

Shapiro, B. P. (1988). What the hell is market oriented? Harvard Business Review, November-December, pp 119-25.

Slater, S. F., \& Narver, J. C. (1998). Market-oriented and customer-led: Let's not confuse the two. Strategic Management Journal, 19(10), $1001-1006$
Slater, S. F., \& Narver, J. C. (1999). Market-oriented is more than being customer-led. Strategic Management Journal, 20(12), $1165-1168$.

Srivastava, R. A., Shervani, T. A., \& Fahey, L. (1999). Marketing, business processes, and shareholder value: An organizationally embedded view of marketing activities and the discipline ofmarketing. Journal of Marketing, 63 (Special Issue), 168-179.

Varadarajan, P. R. (2010). Strategic marketing and marketing strategy: Domain, definition, fundamental issues and foundational premises. Journal of the Academy of Marketing Science, 38(2), 119-140.

Varadarajan, P. R. (2015). Strategic marketing, marketing strategy and market strategy. AMS Review, 5(3), 78-90.

Vorhies, D., \& Morgan, N. A. (2005). Benchmarking marketing capabilities for sustainable Competitive advantage. Journal of Marketing, 69(January), 80-94.

Walker, Orville C., Jr. and Robert W. Ruekert (1987), "Marketing's role in the implementation of business strategies: A critical Review and conceptual framework.” Journal of Marketing, 51 (July), 15-33. 